\title{
Ett viktigt kapitel av de finländska judarnas historia dokumenterat
}

BOKRECENSION

DOI: https://doi.org/10.30752/nj.81274

Kyläkoulu keskellä kaupunkia. Helsingin Juutalainen Yhteiskoulu 100 vuotta [Byskolan mitt i stan. Helsingfors Judiska Samskola 100 år], red. Dan Kantor (ansvarig redaktör), Laura Ekholm, Simo Muir, Riitta Nurmi och Daniel Weintraub (Helsinki, Helsingin Juutalainen Yhteiskoulu, 2018), 211 ss.

Helsingfors judiska samskola är en av de få judiska skolorna i Europa som oavbrutet under ett århundrades tid har förvaltat den gamla mellan- och östeuropeiska judiska skolans arv - ett arv som mestadels försvann i Förintelsens störtvåg. År 2018 fick detta arv en värdig dokumentation i och med att en hundraårshistorik i bokformat publicerades.

Det judiska samfundet i Finland består i dag av ca I 300 medlemmar (som högst har siffran varit omkring 2000 ) och därmed har också de numeriska parametrarna gällande skolan alltid varit små. I det här avseendet blev den en riktig byskola. Judarna i Finland formade aldrig någon shtetl i östeuropeisk mening, utan snarare en by mitt i staden, ett levande nätverk, särpräglat men aldrig stängt, utan i ständig växelverkan med sin omgivning. Och i hjärtat av byn stod, såsom i den finländska landsbygden, helgedomen och skolan - en byskola i mitten av stan.

Staden i detta fall är Helsingfors där de flesta kantonisterna (soldater i den ryska

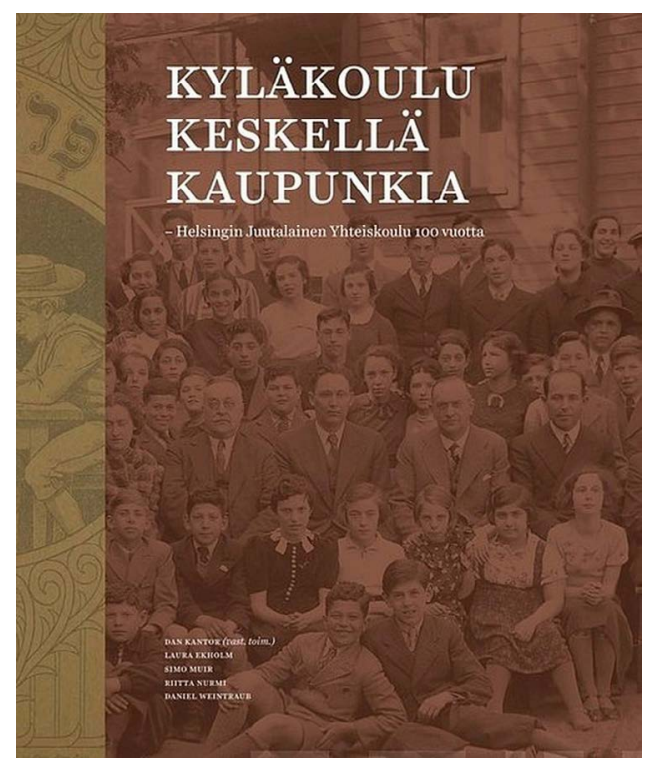

armén som efter sin tjänstgöring stannade kvar i storfurstendömet Finland) bosatte sig och började etablera organiserade former av samfunds- och församlingsliv under den senare hälften av I80o-talet. De första små privata skolorna ("heder"), där pojkar under tre års tid kunde få de grundläggande kunskaperna i hebreiska och judisk religion, grundades redan på i 870-talet. Undervisningen skedde på jiddish. Vid sidan av heder-skolningen gick barnen i stadens svenska och ryska skolor. De första stegen mot en riktig 
judisk skola togs på I 890 -talet och så inledde Judiska Skolan i Helsingfors sin verksamhet I 893 med 6r elever varav I 5 var flickor. Fastän hundraårshistoriken ser dagens ljus år 201 8, firades därför ett roo-års jubileum av den judiska undervisningen i Finland redan år 1993 !

Läsordningen följde i stort sett det program som hade skapats för de statliga skolorna i Ryssland men den judiska religionsundervisningen, med hebreiskan i fokus, fick naturligtvis en särställning. Under åren fram till I9I 8 då judarna äntligen fick medborgarrättigheter i Finland och även skolan fick en etablerad form och officiellt erkänd status, kämpade skolan dels med ekonomiska svårigheter och dels pågick en ideologisk gränsdragning gällande skolans riktning och betoningar i undervisningen. Egentligen följer dessa två aspekter med under hela den hundraåriga historien: hur överleva då det finns brist både på elever och medel (och bristen på de förstnämnda resulterar i nedskurna statliga bidrag) och hurudan skola är det egentligen som judiska föräldrar vill erbjuda åt sina barn: en som leder till en fördjupning av den judiska identiteten eller en som leder till framgång i samhället? Eller går det rentav att hitta en kombination av dessa? Perioden som kan sägas ha varit ett preludium till den nuvarande skolan präglas av ett korsdrag mellan det gamla heder-idealet som lärarna hade tagit med sig bl.a. från Baltikum och nya haskala-inspirerade idéer om skolans modernisering. En annan ideologisk strömning som lämnade sitt avtryck i tidens judiska undervisningsideal var sionismen. Dessa influenser kom till uttryck i den nya skolan som - efter att den första hade lagts ner år I 900 av ekonomiska skäl - grundades r 906 och fick namnet Mosaiska Skolan i Helsingfors. Man kunde skryta med att skolan var en "rent hebräisk skola" (s. 2 I).

År I9I 8 fick Judiska samskolan i Hel- singfors se dagens ljus. Skolan bestod av två steg, en treårig förberedande skola och en $5^{-}$ eller 6-årig mellanskola. En tredje allvarlig utmaning vid sidan av de redan ovannämnda ekonomiska och ideologiska bekymren var behovet av att få de judiska ämnena att rymmas i läsordningen. Läsaren får på olika ställen i historiken läsa om vändningar i värderingar samt om konflikter åtminstone på tre håll: myndigheternas krav på att skolan följer den allmänna läroplanen, församlingens och hemmens (och tidvis rabbinens) förväntningar om hur skolan borde bidra till den delen av uppfostran som hemmet kanske inte kan ge - och för det tredje unga elevers inte alltid så stora entusiasm att studera extra timmar. Upprepade gånger får läsaren också läsa om svårigheter $\mathrm{i}$ att hitta lärare som kunde undervisa hebreiska, eller de judiska ämnena. Utländska lärarkrafter, efter I 948 särskilt från Israel, kom till hjälp. Men samtidigt stötte man på andra slags problem då dessa ofta kortvariga lärare inte kunde folkspråken, vare sig finska eller svenska. På sextiotalet klagade israeliska lärare över att eleverna nog hade någorlunda dugliga passiva kunskaper men inte förmågan att använda hebreiskan (s. I02). Från och med slutet av 1970talet anlitade man inte mer israeliska lärare utan undervisningen i både hebreiska och de judiska ämnena skedde på finska. I dag undervisas hebreiska som ett s.k. A-språk, som inleds redan på första klassen, engelskan kommer med på tredje klassen och senare kommer även andra språk.

När det gäller språkfrågan innehåller skolans historia också ett drag som torde vara unikt i det finländska skolväsendets historia: ett språkbyte. Då judiska familjer under de första årtiondena av Finlands självständighet i allt större utsträckning hade blivit finskspråkiga - och man tänkte sig att skolbildningen på finska skulle ge bättre förutsättningar för att klara sig i samhället - fattade 
man ett beslut om att även skolans språk skall bytas från svenska till finska. Förändringen skedde dock stegvis. Den första årskursen på hösten 1933 inledde sitt skolarbete på finska (fastän det officiella tillståndet för detta från skolmyndigheterna kom först år I 936) och så hade processen slutförts då man kom till krigsåren.

Krigsåren och grundandet av staten Israel i mitten av I900-talet förde med sig omvälvande tider. Kriget betydde svåra år och avbrott i skolåret men verksamheten kördes aldrig ner i sin helhet. Kapitlet "Skolan i krigets skugga" (skrivet av Simo Muir) erbjuder intressanta och rörande minnen från tiden då skolarbetet avbröts $2-3$ gånger per dag på grund av luftlarm och då det i samma stad, bara på några hundra meters avstånd verkade en tysk grundskola och kulturcentret Hindenburghaus som hade hakkorsflaggan på taket (Salomon Furmans minnen, på s. 69). Från och med I 948 blev den unga staten Israel en ny hållpunkt för den judiska identiteten. Israel fick en mer synlig ställning i skolundervisningen och firandet av Israels självständighetsdag blev en del av skolåret.

År 1977 då det finländska skolsystemet fick sin nuvarande form med en 9-årig grundskola omformades även den judiska skolans struktur i enlighet med detta. I det här sammanhanget fick skolan också ett nytt namn: Judiska skolan i Helsingfors. Efter grundskolan söker eleverna till exempel till gymnasier i huvudstadsregionen men återvänder till sin gamla byskola (och synagoga) för religionsundervisning.

I dag, efter $201 \mathrm{I}$, och efter flera namnbyten, heter skolan igen Helsingin Juutalainen Yhteiskoulu (Judiska samskolan i Helsingfors) och den är en livskraftig skola som utan vidare i många avseenden är en garanti för den judiska församlingens fortbestånd och en ögonsten för hela samfundet. Elevantalet har stigit till över Ioo tack vare inflyttningen och resultaten visar höga siffror. Till exempel i matematik har resultaten (2004) visat sig vara $23 \%$ högre än i andra skolor i Helsingfors (s. I6 I-I62). Byskolan har också blivit internationell: bland skoleleverna är ca I 5 olika språk representerade. Tack vare finsk-israeliska äktenskap har antalet elever som talar hebreiska som sitt andra hemspråk stigit över 50\%.

Boken Kyläkoulu keskellä kaupunkia ("Byskolan mitt i stan") är skriven av de bästa tänkbara krafterna: forskarna Simo Muir och Laura Ekholm (båda med tidigare forskning och publikationer angående judiska samfundets historia), skolans långvariga lärare Riitta Nurmi (rektor åren I976-2009) och Daniel Weintraub samt Dan Kantor, församlingens långvariga ombudsman och chefredaktör för församlingens tidskrift Hakebila.

Historiken är inte enbart innehållsrik och som dokumentation en riktig kulturgärning, den är också vacker med tiotals gamla fotografier och originaldokument. Som särskild förtjänst bör omnämnas de utförliga namnlistorna $\mathrm{i}$ anslutning till fotografierna. De många minnen av f.d. elever och lärare, några av dem välkända figurer i Finland, som kryddar sidorna öppnar fönster till den delen av historieskrivningen som inte finns dokumenterad i protokoll och årsberättelser.

Ifall man vill plocka fram kritiska synpunkter så skulle ett något noggrannare redigeringsarbete ha varit till gagn och ökat bokens läsarvänlighet. Olika delkapitel varierar ganska mycket i längd (från nio sidors kap. 4.3 till det följande kapitlet bestående av 36 sidor!) och i viss mån också i stil. Kapitel skrivna av Muir följer en enhetlig plan med ingressartade intron, medan de andra har mer variation. Upprepningar förekommer om dock absolut inte i störande mängd. Det långa kapitlet 4.I "Från krigets skugga mot grundskolan" som täcker hela perioden från kriget till 1977 blir ett slags huvudkapitel i 
boken men är aningen överdimensionerat och skulle ha kunnat spjälkas upp i mindre kronologiska stycken. Högst intressant är det nog. Och fastän det är fråga om petitesser så kunde man också ha önskat att begrepp som jishuv och Bund, skulle ha förklarats för en icke-initierad läsare, då mer grundläggande termer som halacha förklaras.

Simo Muir bär huvudansvaret för beskrivningen av de tidigaste faserna i skolans historia, medan vägen till den nuvarande skolan efter krigsåren i huvudsak målas i de omfattande kapitlen skrivna av skolans nuvarande lärare Daniel Weintraub. Texten är flytande och präglas av pedagogisk skicklighet. Källförteckningarna i slutet av varje avsnitt visar att stora mängder ickepublicerat material har använts och genom intervjuer har en stor mängd icke-skriven information räddats. Några av de intervjuade är redan borta. Rektor Riitta Nurmi behandlar i sina kapitel (3.2 "Samhällets stöd för skolan r 924-I 950 " samt 4.2 "Judiska skolan i Helsingfors status stabiliseras") skolans ställning i förhållande till samhället, och Laura Ekholm belyser den förändrande identiteten genom sina presentationer (3.4"Skolan byter undervisningsspråke"t; 4.4 "Århundradets generationer") som dels behandlar bytet av språk och dels den information som namnlistorna erbjuder: i val av förnamn och valet att översätta gamla släktnamn dels till finska, dels till hebreiska varianter.

Genom boken har ett viktigt kapitel i den finländska judendomens historia dokumenterats.

PEKKA LINDOVIST

TD, universitetslärare i exegetik och judaistik, Åbo Akademi 